\title{
PENGARUH MODEL PEMBELAJARAN KOOPERATIF DAN KECERDASAN INTERPERSONAL TERHADAP HASIL BELAJAR MATEMATIKA
}

\author{
Nurmasdalifah \\ Guru SD Negeri 060805 Medan \\ iffah.muth@yahoo.co.id
}

\begin{abstract}
Abstrak: Tujuan penelitian untuk mengetahui; (1) pengaruh model pembelajaran kooperatif terhadap hasil belajar, (2) pengaruh kecerdasan interpersonal terhadap hasil belajar dan (3) untuk mengetahui interaksi antara model pembelajaran kooperatif dan kecerdasan interpersonal terhadap hasil belajar Matematika. Penelitian kuasi eksperimen, dengan total populasi berjumlah 120 siswa. Sampel 60 siswa. Hasil menunjukkan bahwa; (1) siswa yang diajar menggunakan model pembelajaran kooperatif Two Stay Two Stray, memperoleh hasil belajar yang lebih tinggi dibandingkan kooperatif Number Head Together; (2) Siswa yang memiliki tingkat kecerdasan interpersonal tinggi memperoleh hasil belajar yang lebih tinggi dibandingkan kecerdasan interpersonal rendah; (3) Terdapat interaksi antara model pembelajaran kooperatif dan kecerdasan interpersonal terhadap hasil belajar Matematika. Uji lanjutan Schefee diperoleh bahwa siswa yang memiliki tingkat kecerdasan interpersonal tinggi jika diajar menggunakan model pembelajaran kooperatif Two Stay Two Stray memperoleh hasil belajar Matematika yang lebih tinggi dibandingkan menggunakan model pembelajaran kooperatif Number Head Together. Siswa yang memiliki tingkat kecerdasan interpersonal rendah memperoleh hasil belajar Matematika yang lebih tinggi jika diajar menggunakan model pembelajaran kooperatif Number Head Together dibandingkan kooperatif Two Stay Two Stray.
\end{abstract}

Kata Kunci : model pembelajaran kooperatif, kecerdasan interpersonal, matematika

Abstract: The objective of the research is to know; (1) the influence of cooperative learning model on learning outcomes, (2) the influence of interpersonal intelligence on learning outcomes and (3) to know the interaction between cooperative learning model and interpersonal intelligence on mathematics learning outcomes. Quasi experimental research, with a total population of 120 students. Sample 60 students. The results show that; (1) students who were taught using Two Stay Two Stray cooperative learning model, obtained higher learning outcomes than the cooperative Number Head Together; (2) Students with high levels of interpersonal intelligence gain higher learning outcomes than low interpersonal intelligence; (3) There is an interaction between cooperative learning model and interpersonal intelligence on mathematics learning outcomes. Schefee advanced test found that students who have high levels of interpersonal intelligence when taught using cooperative learning model Two Stay Two Stray obtained higher learning outcomes than using cooperative learning model Head Head Together. Students who have a low level of interpersonal intelligence acquire higher mathematics learning outcomes if taught using cooperative learning model Number Head Together than Two Stay Two Stray cooperative.

Keywords: cooperative learning model, interpersonal intelligence, mathematics

\section{PENDAHULUAN}

Salah satu tujuan nasional yang berhubungan dengan pendidikan tercantum pada pembukaan UUD 1945 alinea 4 yaitu mencerdaskan kehidupan bangsa. Hal ini juga sesuai dengan UU RI No.2 tahun 1989, sistem pendidikan nasional pasal 4 tentang tujuan pendidikan nasional yaitu manusia yang beriman dan bertakwa kepada Tuhan Yang Maha Esa yang berbudi pekerti luhur, memiliki pengetahuan dan keterampilan kesehatan jasmani dan rohani, kepribadian yang mantap dan mandiri serta rasa tanggung jawab kemasyarakatan dan kebangsaan.

Kita sering menjumpai hal-hal yang berhubungan dengan matematika. Mulai dari bentuk bangunan di sekitar kita, kegiatan jual beli di pasar, pada saat menabung uang di bank, pada tabel, grafik, diagram, persamaan dan lainlain. Tampaknya kita tidak bisa memungkiri 
sebuah ungkapan matematika merupakan bagian yang tak terpisahkan dalam kehidupan seseorang.

Pelajaran matematika adalah salah satu pelajaran yang dipelajari siswa mulai dari jenjang SD sampai perguruan tinggi. Banyak di antara para siswa SD ini yang menganggap pelajaran matematika sebagai pelajaran yang menakutkan, tidak menarik, membosankan, dan sulit. Tentu saja hal ini sangat memprihatinkan karena jenjang SD merupakan tingkat dasar dari seluruh proses pendidikan yang akan dijalani anak.

Supatmono (2009:5) menyatakan bahwa: secara etimologi, matematika berasal dari bahasa latin manthanein atau mathemata yang berarti 'belajar atau hal yang dipelajari' ("thinks that are learned"). Dalam bahasa Belanda disebut wiskunde atau ilmu pasti, yang kesemuana berkaitan dengan penalaran. Matematika dapat dipandang sebagai pelayan (servant) dan sekaligus ratu (queen) dari ilmuilmu yang lain. Sebagai pelayan, matematika adalah ilmu dasar yang mendasari dan melayani berbagai ilmu pengetahuan yang lain. Tidak mengherankan apabila dalam fungsinya sebagai pelayan ilmu yang lain, matematika muncul di ilmu kimia, fisika, biologi, astronomi, psikologi dan masih banyak yang lain. Sebagai ratu, perkembangan matematika tidak tergantung pada ilmu-ilmu lain. Banyak cabang matematika yang dulu biasa disebut matematika murni, dikembangkan menjadi kalkulus, geometri, aritmatika, aljabar, dan cabang matematika lainnya.

Untuk membedakan antara banyak sedikit, lebih dengan kurang, orang perlu berhitung. Misalnya seorang gembala akan menghitung apakah kambing yang masuk ke kandang pada sore hari sudah lengkap atau belum, gembala tersebut menggunakan tumpukan batu yang jumlahnya sama dengan jumlah kambing. Setiap kambing masuk satu maka tumpukan dipindahkan satu. Apabila ada tumpukan batu yang tersisa berarti ada kambing yang belum masuk kandang dan dengan demikian jumlah kambing yang masuk kandang kurang dari jumlah semula. Praktik seperti ini adalah permulaan orang berhitung, yang kelak kemudian hari akan menjadi tumbuhnya cabang baru dalam matematika.

Riedesel,

dkk.

(1996:10-11), merangkum pandangan matematika: (1) setiap soal matematika mempunyai tepat sebuah jawaban yang benar, (2) matematika adalah kumpulan kebenaran dan aturan. Tugas siswa adalah mengikuti aturan itu untuk menemukan jawaban yang benar. Biasanya aturan yang harus dipakai adalah yang diajarkan guru, (3) siswa tidak perlu mengerti mengapa suatu aturan berlaku, tetapi cukup menghafalkan saja, (4) jika dalam tempo lima menit suatu soal tidak dapat dipecahkan, berarti tidak dapat memecahkannya. Lebih baik berhenti saja, (5) hanya para jenius sajalah yang dapat menemukan atau dapat menciptakan matematika. Siswa tidak dapat memikirkan matematika menurut pikirannya sendiri, dan (6) soal matematika hampir tidak ada hubungannya dengan dunia nyata. Dalam dunia nyata, kita mengerjakan apa yang bermakna, sedangkan dalam matematika kita tinggal menuruti aturan-aturan.

Tidak jauh berbeda dengan yang disampaikan Riedesel, dkk., Prof. Dr. Andi Hakim Nasution, pakar Matematika Institut Pertanian Bogor menyebutkan bahwa matematika merupakan: " ilmu struktur, urutan (order), dan hubungan yang meliputi dasar-dasar perhitungan, pengukuran, dan penggambaran bentuk objek. Ilmu ini melibatkan logika dan kalkulasi kuantitatif, dan pengembangannya telah meningkatkan derajat idealisasi dan abstraksi subjeknya. Semakin orang banyak ditanya apa itu matematika, semakin banyak pula pengertian tentang matematika.

Begitu banyak syarat yang harus dimiliki siswa diantaranya adalah persiapan kesiapan belajar dan fasilitas. Sebab banyak kesulitan belajar matematika sehingga membutuhkan upaya dan sikap inovasi yang maksimal dari siswa maupun guru. Proses pembelajaran yang terjadi sering menjadikan siswa lebih menerima apa adanya semua penjelasan dari guru tanpa dimengerti sama sekali, yang akibatnya siswa menjadi tidak aktif - Oleh karena itu, diperlukan keaktifan untuk bisa mempelajari dan memahami matematika. Pelajaran matematika adalah salah satu pelajaran yang dipelajari siswa mulai dari jenjang pendidikan terendah sampai perguruan tinggi. Matematika memegang peranan penting karena belajar matematika harus secara benar. Meski tidak semua, banyak di antara siswa sekolah yang mengeluhkan pelajaran matematika. Tentu saja hal ini sangat mempengaruhi pada hasil belajar siswa pada matematika. Ada kemungkinan dari penyebab rendahnya hasil belajar siswa pada matematika disebabkan beberapa faktor seperti minat, motivasi siswa yang kurang, penyampaian konsep dan materi 
yang kurang jelas ataupun pendekatan, strategi, model pembelajaran maupun metode yang kurang tepat. Memang kita tidak bisa menyalahkan siapa-siapa dalam hal ini. Seharusnya sistem pendidikan di Indonesia seperti layaknya kereta api. Sekolah haruslah menjadi gerbong, dengan dinas pendidikan sebagai lokomotifnya. Keuntungannya, setiap tingkatan pendidikan memiliki akses yang luas sehingga tidak ada batasan untuk saling menunjang, baik dari segi sarana maupun prasarana pendidikan. Pembelajaran yang berhasil dapat ditunjukkan oleh penguasaan materi yang cukup baik oleh siswa, dan dapat dibuktikan dengan perolehan nilai yang memenuhi kriteria ketuntasan minimal dari hasil evaluasi di akhir pembelajaran dari materi yang disajikan.

SD Negeri Jalan Kakap adalah salah satu sekolah di kota Medan didirikan tanggal 27 April 1968 yang terdiri dari SD Negeri 060805 dan SD Negeri 060806 Medan. Penelitian dilaksanakan di kelas IV yang seluruhnya ada empat kelas dengan jumlah 120 orang, dimana dalam satu kelas terdapat 30 siswa dan sampelnya hanya dua kelas saja. Berdasarkan wawancara penulis dengan guru mata pelajaran matematika di SD Negeri 060805 dan SD Negeri 060806 Medan, masalah yang dihadapi siswa dalam pembelajaran matematika adalah kurangnya antusias siswa selama pembelajaran. Siswa lebih cenderung menerima apa saja yang disampaikan guru, diam dan enggan dalam mengungkapkan pertanyaan maupun pendapat. Data hasil belajar matematika siswa selama ini belum menunjukkan hasil optimal dengan nilai Kriteria Ketuntasan Minimal (KKM) matematika 65 (enam puluh lima). Hal ini dapat dilihat pada hasil belajar Ujian Akhir Semester mata pelajaran matematika kelas IV SD Negeri Jalan Kakap Medan Tahun Pelajaran 2007 s/d 2013.

Disamping itu kegiatan pembelajaran matematika di SD Negeri Jalan Kakap Medan masih berjalan secara konvensional, dimana masih didominasi kegiatan ceramah dan berpusat pada guru. Proses pembelajaran yang terjadi sering menjadikan siswa lebih menerima apa adanya semua penjelasan dari guru tanpa dimengerti sama sekali, yang akibatnya siswa menjadi tidak aktif. Siswa lebih cenderung menerima apa saja yang disampaikan guru, diam dan enggan dalam mengungkapkan pertanyaan maupun pendapat. Untuk mengatasi masalah tersebut, guru harus bisa memilih metode atau model pembelajaran yang dapat membuat pelajaran matematika menjadi lebih menyenangkan dan dapat memancing siswa untuk mempelajari matematika. Guru dituntut untuk berusaha mengaktifkan siswa selama proses pembelajaran matematika sehingga matematika dapat dipahami dengan baik dan diharapkan dapat meningkatkan hasil belajar siswa.

Mata pelajaran matematika di SD merupakan kumpulan pengetahuan tentang perhitungan, pengukuran dan penggambaran objek. Salah satu materi dalam matematika di kelas IV adalah bangun ruang. Bangun ruang yang dibahas di kelas IV adalah kubus dan balok. Kubus adalah sebuah benda ruang yang ditutup oleh enam buah persegi yang berukuran sama dan mempunyai panjang rusuk sama. Bangun ruang kubus terbentuk dari bangun datar persegi. Gabungan dari beberapa persegi yang membentuk kubus dinamakan jaring-jaring kubus. Sifat-sifat kubus berkaitan dengan sisi, rusuk, dan titik sudut. Sisi adalah bidang atau permukaan yang membatasi bangun ruang. Rusuk adalah garis yang merupakan pertemuan dari dua sisi bangun ruang. Titik sudut adalah titik pertemuan dari tiga buah rusuk pada bangun ruang. Sisi-sisi kubus berbentuk persegi yang berukuran sama yang berjumlah 6 buah, rusuk kubus mempunyai panjang yang sama yang berjumlah 12 buah, dan titik sudut kubus ada 8 buah. Balok adalah bangun ruang yang ditutup oleh enam buah persegi yang berhadapan, yang panjang rusuk tiap pasangan berbeda dengan pasangan lainnya. Gabungan dari beberapa persegi panjang yang membentuk balok dinamakan jaring-jaring balok. Terkadang siswa sulit untuk memahami perbedaan kubus dan balok hanya dari penyampaian guru saja. Sebagai makhluk sosial, seseorang harus berinteraksi sosial dengan manusia lainnya. Oleh sebab itu siswa perlu berinteraksi dengan siswa lain agar tercipta pembelajaran lebih efektif dalam menciptakan komunikasi yang multi arah, sehingga diharapkan juga menimbulkan dan meningkatkan interaksi yang proaktif dalam pembelajaran. Untuk itu, guru diharapkan mampu membentuk kelompok-kelompok dengan berhati-hati agar semua anggotanya dapat bekerja bersama-sama untuk memaksimalkan pembelajarannya sendiri dan pembelajaran teman-teman satu kelompoknya. Masing-masing anggota kelompok bertanggung jawab mempelajari apa yang disajikan dan 
membantu teman-teman anggota untuk mempelajarinya juga.

Salah satu usaha yang dapat dilakukan guru agar siswa aktif, antusias, dan mampu bekerja sama dalam belajar matematika adalah melalui penggunaan model pembelajaran kooperatif. Model pembelajaran kooperatif merupakan bentuk kegiatan pembelajaran dengan cara siswa belajar dan bekerja dalam kelompok-kelompok kecil yang memilki struktur kelompok yang heterogen dengan mempertimbangkan keragaman karakteristik siswa misalnya kecerdasan.

Kecerdasan merupakan salah satu faktor internal dan sebagai faktor utama yang menentukan sukses gagalnya siswa belajar. Gardner mempunyai pandangan bahwa kecerdasan bukanlah sesuatu yang bersifat tetap. Kecerdasan bersifat laten, ada pada setiap manusia dengan kadar pengembangan yang berbeda pula. Pembelajaran kooperatif berbeda dengan pembelajaran yang lain. Perbedaan tersebut dapat dilihat dari proses pembelajaran yang lebih menyangkut pada unsur kecerdasan interpersonal para siswa. Kecerdasan interpersonal menunjukkan kemampuan siswa dalam menjalin komunikasi secara efektif, mampu berempati secara baik, dan kemampuan mengembangkan hubungan yang harmonis dengan orang lain (Gardner:1999). Misalnya model pembelajaran kooperatif dalam memahami materi bangun ruang kubus dan balok. Disini setiap siswa menunjukkan bagaimana siswa saling percaya, menghargai perbedaan, mendorong anggotanya mengemukakan pendapat, menjadi pendengar dan penanya yang baik, menanggapi kebutuhan orang lain, dan pengendalian diri dengan tidak mudah menyalahkan orang lain. Sehingga setiap anggota kelompok dapat memahami matematika materi bangun ruang kubus dan balok.

Model pembelajaran kooperatif belum banyak diterapkan dalam pendidikan walaupun orang Indonesia sangat membanggakan sifat gotong royong dalam kehidupan bermasyarakat. Sebenarnya, pembagian kerja kelompok jika pengajar benar-benar menerapkan prosedur model pembelajaran kooperatif. Model pembelajaran kooperatif tidak sama dengan sekedar belajar dalam kelompok. Ada unsurunsur dasar dengan pembagian kelompok yang dilakukan asal-asalan. Pelaksanaan prosedur model pembelajaran kooperatif dengan benar akan memungkinkan pendidik mengelola kelas dengan lebih efektif.
Dalam penerapannya model pembelajaran kooperatif dapat mengubah peran guru dari peran terpusat pada guru ke peran pengelola kegiatan kelompok-kecil. Dengan demikian, model pembelajaran kooperatif bergantung pada efektivitas kelompokkelompok siswa tersebut. Singkatnya, model pembelajaran kooperatif mengacu pada kegiatan pembelajaran di mana siswa bekerja sama dalam kelompok kecil dan saling membantu dalam belajar dengan kecerdasan interpersonal. Model pembelajaran kooperatif umumnya melibatkan kelompok yang terdiri dari 4 siswa dengan kemampuan yang berbeda dan ada pula yang menggunakan kelompok dengan ukuran yang berbeda-beda.

Model pembelajaran kooperatif biasanya menempatkan siswa dalam kelompokkelompok kecil. Sebelumnya, kelompokkelompok siswa ini diberi penjelasan/pelatihan tentang: bagaimana menjadi pendengar yang baik, bagaimana memberi penjelasan dengan baik, bagaimana mengajukan pertanyaan yang baik, dan bagaimana saling membantu dan menghargai satu sama lain dengan cara-cara yang baik pula.

Konsekuensi positif dari model pembelajaran ini adalah siswa diberi kebebasan untuk terlibat secara aktif dalam kelompok mereka. Dalam lingkungan model pembelajaran kooperatif, siswa harus menjadi partisipan aktif dan melalui kelompoknya, dapat membangun komunitas pembelajaran (learning community) yang saling membantu antarsatu sama lain.

Sebagian besar penelitian tentang model pembelajaran kooperatif mulai berkembang pada tiga dekade terakhir abad kedua puluh. Setidak-tidaknya, ada empat persfektif teoritis yang mendasari pembelajaran kooperatif ini; persfektif motivasional (motivational perspective), persfektif kohesi sosial (sosial cohesion perspektive), persfektif kognitif (cognitive perspective), dan persfektif perkembangan (developmental persfektive). (Miftahul Huda: 33: 2011).

Menyusun model pembelajaran kooperatif melibatkan lebih dari sekedar menempatkan beberapa orang siswa duduk bersama dan menyuruh mereka untuk saling membantu satu sama lain. Kondisi-kondisi ini adalah komponen-komponen esensial yang membuat kegiatan kooperatif dan individualistik. Komponen-komponen esesnsial ini adalah: melihat secara jelas, interdepensi positif, interaksi mendukung (tatap muka) yang 
cukup besar, melihat secara jelas tanggung jawab individual dan tanggung jawab personal untuk mencapai tujuan-tujuan kelompok, sering menggunakan skil-skil kelompok kecil atau kecerdasan interpersonal yang relevan, dan pemrosesan kelompok yang cukup sering dan teratur terhadap pemungsian saat ini untuk mengembangkan keefektifan di waktu berikutnya.

Salah satu aspek terpenting model pembelajaran kooperatif adalah kecerdasan interpersonal. Peran memonitor seorang guru menitikberatkan pada siswa ketika mereka sedang bekerja sama mengumpulkan informasi dan menyampaikan informasi sehingga standar kompetensi yang diharapkan tercapai.

Ada beberapa variasi jenis model dalam pembelajaran kooperatif. Beberapa diantaranya adalah Jigsaw, Group Investigation (GI), Team Accelerated Instruction (TAI), Think Pair Share (TPS), Student Team Achievement Divisions (STAD),Team Games Tournament (TGT), Two Stay Two Stray (TS-TS), dan Numbered Head Together (NHT). Penulis mencoba melihat hasil belajar siswa melalui dua model kooperatif saja yang sesuai dengan materi bangun ruang yaitu Model Pembelajaran Kooperatif Teknik Two Stay Two Stray (TS-TS) dengan Model Pembelajaran Kooperatif Teknik Numbered Head Together (NHT).

Teknik TS-TS membagi siswa dalam kelompok yang terdiri dari empat orang. Dua orang sebagai tamu dan dua orang yang lain tetap tinggal di kelompok untuk membagi hasil diskusi ke tamu. Teknik NHT merupakan teknik belajar mengajar kepala bernomor. Teknik ini membagi siswa dalam kelompok yang terdiri dari empat sampai enam orang dimana setiap masing-masing siswa mendapat nomor, dan nomor yang dipanggil harus melaporkan hasil kerja. Kecerdasan interpersonal tinggi menunjukkan kemampuan siswa dalam menjalin komunikasi secara efektif, mampu berempati secara baik, dan kemampuan mengembangkan hubungan yang harmonis dengan orang lain, maka diduga lebih tepat dipadukan dengan Model Pembelajaran Kooperatif TS-TS, karena siswa harus menanya dan menjawab pertanyaan sehingga perlu kecerdasan interpersonal tinggi. Sedangkan siswa yang memiliki kecerdasan interpersonal rendah diduga lebih tepat dipadukan dengan Model Pembelajaran Kooperatif NHT karena fokus hanya pada individual nomor yang akan dipanggil maju ke depan.
Berdasarkan latar belakang tersebut, penulis akan meneliti "Pengaruh Model Pembelajaran Kooperatif dan Kecerdasan Interpersonal terhadap Hasil Belajar Matematika siswa pada Pokok Bahasan Bangun Ruang di kelas IV SD Negeri Jalan Kakap Medan Tahun Pelajaran 2013/2014".

Dari identifikasi dan pembatasan masalah dapat dirumuskan permasalahan dalam penelitian ini sebagai berikut ini; (1) Apakah hasil belajar Matematika siswa yang diajar menggunakan model pembelajaran kooperatif Two stay Two Stray lebih tinggi dari pada siswa yang diajar menggunakan model pembelajaran kooperatif Numbered Head Together?; (2) Apakah hasil belajar siswa yang memiliki tingkat kecerdasan interpersonal tinggi lebih tinggi dari pada siswa yang memiliki tingkat kecerdasan interpersonal rendah?; (3) Apakah ada interaksi antara model pembelajaran kooperatif dan kecerdasan interpersonal dalam mempengaruhi hasil belajar Matematika?

\section{METODE}

Penelitian dilaksanakan di SD Negeri Jalan Kakap yaitu SD Negeri 060805 Medan dan SD Negeri 060806 Medan. Penelitian ini dilakukan pada siswa kelas IV. Waktu penelitian disesuaikan dengan kalender pendidikan SD Negeri Jalan Kakap Medan. Populasi dalam penelitian ini adalah seluruh siswa kelas IV semester II. Teknik yang digunakan dalam menentukan sampel pada penelitian ini adalah Sampel Acak Kelompok (Cluster Random Sampling), yaitu dengan menuliskan nama keempat kelas ke dalam kotak. Kemudian 2 (dua) kertas dicabut untuk dijadikaan kelas sampel.

Dari undaian ini tercabut kelas IVA SD 05dan kelas IVA SD 06. Selanjutnya menentukan kelas yang diberi perlakuan diundi lagi dengan menggulung dan memasukkan kedua kertas kecil yakni kelas IVA SD 05 dan kelas IVA SD 06 ke dalam kotak. Kertas yang tercabut dikenai model pembelajaran kooperatif Two Stay Two Stray dan yang tidak tercabut dikenai model pembelajaran kooperatif Number Head Together. Dari undian tersebut diperoleh kelas IVA SD 05 yang dikenai model pembelajaran kooperatif Two Stay Two Stray, sedangkan kelas IVA SD 06 dikenai model pembelajaran kooperatif Number Head Together. Dari kelas sampel yang terpilih, semua siswa diberikan tes kecerdasan interpersonal untuk mengetahui kecenderungan tingkat 
kecerdasan interpersonal siswa dengan cara membagi dua dari jumlah sampel setiap kelas, sehingga diperoleh tingkat kecerdasan interpersonal tinggi dan tingkat kecerdasan interpersonal rendah. Penelitian ini menggunakan metode kuasi eksperimen.

Eksperimen dilakukan terhadap satu kelas yang diberi perlakuan model pembelajaran kooperatif Two Stay Two Stray, dan satu kelas lagi diberi perlakuan model pembelajaran kooperatif Number Head Together. Penelitian ini menggunakan rancangan faktorial $2 \times 2$ dengan membandingkan rata-rata hasil belajar kelompok siswa yang diajar menggunakan model pembelajaran kooperatif Two Stay Two Stray dan kelompok siswa yang diajar menggunakan model pembelajaran kooperatif Number Head Together dan ditinjau dari tingkat kecerdasan interpersonal siswa sebagai variable moderator.

\section{HASIL}

Dari hasil penelitian di lapangan diketahui bahwa siswa yang diajar menggunakan model pembelajaran kooperatif Two Stay Two Stray memperoleh $\mathrm{nA}_{1}=30 ; \quad \bar{X} \mathrm{~A}_{1}=19,77$; $\mathrm{SA}_{1}=3,58$. Berikut ini disajikan Tabel 1 perbandingan data hasil belajarMatematika siswa berdasarkan model pembelajaran kooperatif dan kecerdasan interpersonal siswa.

Tabel 1. Perbandingan Data Hasil Belajar Matematika Siswa berdasarkan Model Pembelajaran Kooperatif dan Kecerdasan Interpersonal Siswa

\begin{tabular}{|l|c|c|c|c|c|}
\hline Sumber Varians & $\mathbf{d k}$ & $\mathbf{J K}$ & $\mathbf{R J K}$ & $\mathbf{F h}$ & $\mathbf{F}_{\mathbf{0}, \mathbf{0 5}(\mathbf{1 , 5 6})}$ \\
\hline Antar baris & 1 & 225,54 & $\begin{array}{c}225,5 \\
4\end{array}$ & $\begin{array}{c}32,1 \\
5\end{array}$ & 4,02 \\
\hline Antar Kolom & 1 & 81,67 & 81,67 & $\begin{array}{c}11,6 \\
7\end{array}$ & 4,02 \\
\hline Interaksi & 1 & 33,44 & 33,44 & 4,77 & 4,02 \\
\hline Dalam kelompok & 56 & 392,63 & 7,01 & - & - \\
\hline
\end{tabular}

Rangkuman pengujian hipotesis pengaruh model pembelajaran kooperatif dan kecerdasan interpersonal terhadap hasil belajar Matematika siswa, dapat dilihat pada Tabel 2 berikut ini:

Tabel 2. Rangkuman Pengujian Hipotesis Pengaruh Model Pembelajaran Kooperatif dan Kecerdasan Interpersonal Siswa Terhadap Hasil Belajar Matematika

\begin{tabular}{|l|l|l|l|}
\hline & \multicolumn{2}{|l|}{ Model Pembelajaran Kooperatif } & \\
\hline Kecerdasan Interpersonal & \multicolumn{1}{|c|}{ TS-TS $\left(\mathrm{A}_{1}\right)$} & \multicolumn{1}{c|}{ NHT $\left(\mathrm{A}_{2}\right)$} & \multicolumn{1}{c|}{ Total } \\
\hline Tinggi $\left(\mathrm{B}_{1}\right)$ & $\mathrm{n}_{1}=15$ & $\mathrm{n}_{2}=14$ & $\mathrm{nB}_{1}=29$ \\
& $\bar{X}_{1}=22,13$ & $\bar{X}_{2}=19,28$ & $\bar{X} \mathrm{~B}_{1}=20,76$ \\
& $\mathrm{~S}_{1}=3,14$ & $\mathrm{~S}_{2}=2,2$ & $\mathrm{SB}_{1}=3,03$ \\
\hline Rendah $\left(\mathrm{B}_{2}\right)$ & $\mathrm{n}_{3}=15$ & $\mathrm{n}_{4}=16$ & $\mathrm{nB}_{2}=31$ \\
& $\bar{X}_{3}=17,4$ & $\bar{X}_{4}=15,81$ & $\bar{X} \mathrm{~B}_{2}=16,58$ \\
& $\mathrm{~S}_{3}=2,72$ & $\mathrm{~S}_{4}=3,04$ & $\mathrm{SB}_{2}=2,89$ \\
\hline Total & $\mathrm{nA}_{1}=30$ & $\mathrm{nA}_{2}=30$ & $\mathrm{n}_{\mathrm{t}}=60$ \\
& $\bar{X} \mathrm{~A}_{1}=19,77$ & $\bar{X}_{2}=17,47$ & $\bar{X}_{\mathrm{t}}=18,6$ \\
& $\mathrm{SA}_{1}=3,58$ & $\mathrm{SA}_{2}=3,12$ & $\mathrm{~S}_{\mathrm{t}}=5,59$ \\
\hline
\end{tabular}

Karena ada interaksi antara model pembelajaran kooperatif dengan kecerdasan interpersonal dalam mempengaruhi hasil belajar, maka dilakukanlah uji lanjutan, yaitu untuk mengetahui perbedaan ratarata hasil belajar setiap kelompok sampel. Adapun uji lanjut yang dingunakan adalah uji Schefee. Untuk rangkuman hasil uji Schefee, dapat diperhatikan pada Tabel 3 berikut ini:

Tabel 3. Rangkuman Hasil Uji Schefee

\begin{tabular}{|l|c|c|c|c|}
\hline No & Komparasi Antar Kelompok & $\mathrm{F}_{\text {hitung }}$ & $\mathrm{F}_{\text {tabel }}\left(3 \mathrm{xF}_{0,05 ; 3 ; 56}\right)$ & Keterangan \\
\hline 1 & $\mathrm{~A}_{1} \mathrm{~B}_{1}$ dengan $\mathrm{A}_{1} \mathrm{~B}_{2}$ & 22,37 & 4,16 & Signifikan \\
\hline
\end{tabular}




\begin{tabular}{|l|c|c|c|c|}
\hline 2 & $\mathrm{~A}_{1} \mathrm{~B}_{1}$ dengan $\mathrm{A}_{2} \mathrm{~B}_{1}$ & 184,71 & 4,16 & Signifikan \\
\hline 3 & $\mathrm{~A}_{1} \mathrm{~B}_{1}$ dengan $\mathrm{A}_{2} \mathrm{~B}_{2}$ & 138,83 & 4,16 & Signifikan \\
\hline 4 & $\mathrm{~A}_{1} \mathrm{~B}_{2}$ dengan $\mathrm{A}_{2} \mathrm{~B}_{1}$ & 72,93 & 4,16 & Signifikan \\
\hline 5 & $\mathrm{~A}_{1} \mathrm{~B}_{2}$ dengan $\mathrm{A}_{2} \mathrm{~B}_{2}$ & 70,99 & 4,16 & Signifikan \\
\hline 6 & $\mathrm{~A}_{2} \mathrm{~B}_{1}$ dengan $\mathrm{A}_{2} \mathrm{~B}_{2}$ & 535,06 & 4,16 & Signifikan \\
\hline
\end{tabular}

Berdasarkan hasil uji Schefee pada Tabel 3 dapat dilihat bahwa terdapat 6 (enam) pasang hipotesis statistik yaitu :

a. Ada perbedaan yang signifikan antara hasil belajar matematika kelompok siswa yang memiliki kecerdasan interpersonal tinggi diajarkan dengan model pembelajaran kooperatif TS-TS $\left(\mathrm{A}_{1} \mathrm{~B}_{1}\right)$ dibandingkan kelompok siswa yang memiliki kecerdasan interpersonal rendah dengan model pembelajaran kooperatif $\quad$ TS-TS $\left(\mathrm{A}_{1} \mathrm{~B}_{2}\right)$ dengan $\quad F_{\text {hitung }}>F_{\text {tabel }}$ yaitu $22,37>4,16$. Berdasarkan skor rata-rata tampak bahwa hasil belajar matematika siswa yang memiliki kecerdasan interpersonal tinggi diajarkan dengan model pembelajaran kooperatif TSTS $(22,13)$ memperoleh hasil belajar matematika yang lebih tinggi dan lebih baik dibandingkan hasil belajar matematika siswa yang memiliki kecerdasan interpersonal rendah diajarkan dengan model pembelajaran kooperatif TS-TS $(17,4)$.

b. Ada perbedaan yang signifikan antara hasil belajar matematika kelompok siswa yang memiliki kecerdasan interpersonal tinggi diajarkan dengan model pembelajaran kooperatif TS-TS $\left(\mathrm{A}_{1} \mathrm{~B}_{1}\right)$ dibandingkan kelompok siswa yang memiliki kecerdasan interpersonal tinggi diajarkan dengan model pembelajaran kooperatif $\mathrm{NHT} \quad\left(\mathrm{A}_{2} \mathrm{~B}_{1}\right)$ dengan $\quad F_{\text {hitung }}>F_{\text {tabel }}$ yaitu $184,71>4,16$. Berdasarkan skor rata-rata tampak bahwa kelompok siswa yang memiliki kecerdasan interpersonal tinggi diajarkan dengan model pembelajaran kooperatif TS-TS $(22,13)$ memperoleh hasil belajar matematika yang lebih tinggi atau lebih baik dibandingkan kelompok siswa yang memiliki kecerdasan interpersonal tinggi diajarkan dengan model pembelajaran kooperatif NHT $(19,29)$.

c. Ada perbedaan yang signifikan antara hasil belajar matematika kelompok siswa yang memiliki kecerdasan interpersonal tinggi diajarkan dengan model pembelajaran kooperatif TS-TS $\left(\mathrm{A}_{1} \mathrm{~B}_{1}\right)$ dibandingkan kelompok siswa yang memiliki kecerdasan interpersonal rendah diajarkan dengan model pembelajaran kooperatif NHT $\left(\mathrm{A}_{2} \mathrm{~B}_{2}\right)$ dengan $\quad F_{\text {hitung }}>F_{\text {tabel }} \quad$ yaitu $138,83>4,16$. Berdasarkan skor rata-rata tampak bahwa kelompok siswa yang memiliki kecerdasan interpersonal tinggi diajarkan dengan model pembelajaran kooperatif TS-TS $(22,13)$ memperoleh hasil belajar matematika yang lebih tinggi atau lebih baik dibandingkan kelompok siswa yang memiliki kecerdasan interpersonal rendah diajarkan dengan model pembelajaran kooperatif NHT $(15,81)$.

d. Ada perbedaan yang signifikan antara hasil belajar matematika kelompok siswa yang memiliki kecerdasan interpersonal rendah diajarkan dengan model pembelajaran kooperatif TS-TS $\left(\mathrm{A}_{1} \mathrm{~B}_{2}\right)$ dibandingkan kelompok siswa yang memiliki kecerdasan interpersonal tinggi diajarkan dengan model pembelajaran kooperatif NHT $\left(\mathrm{A}_{2} \mathrm{~B}_{1}\right)$ dengan $\quad F_{\text {hitung }}>F_{\text {tabel }}$ yaitu 72,93>4,16. Berdasarkan skor rata-rata tampak bahwa kelompok siswa yang memiliki kecerdasan interpersonal rendah diajarkan dengan model pembelajaran kooperatif TS-TS $(17,4)$ memperoleh hasil belajar matematika yang lebih tinggi atau lebih baik dibandingkan kelompok siswa yang memiliki kecerdasan interpersonal tinggi diajarkan dengan model pembelajaran kooperatif NHT $(19,29)$.

e. Ada perbedaan yang signifikan antara hasil belajar matematika kelompok siswa yang memiliki kecerdasan interpersonal rendah diajarkan dengan model pembelajaran kooperatif TS-TS $\left(\mathrm{A}_{1} \mathrm{~B}_{2}\right)$ dibandingkan kelompok siswa yang memiliki kecerdasan interpersonal rendah diajarkan dengan model pembelajaran kooperatif NHT $\left(\mathrm{A}_{2} \mathrm{~B}_{2}\right)$ dengan $\quad F_{\text {hitung }}>F_{\text {tabel }}$ yaitu $70,99>4,16$. Berdasarkan skor rata-rata tampak bahwa kelompok siswa yang memiliki kecerdasan interpersonal rendah diajarkan dengan model pembelajaran kooperatif TS-TS $(17,4)$ memperoleh hasil belajar matematika yang lebih tinggi atau lebih baik dibandingkan kelompok siswa yang memiliki kecerdasan interpersonal rendah diajarkan dengan model pembelajaran kooperatif NHT $(15,81)$.

f. Ada perbedaan yang signifikan antara hasil belajar matematika kelompok siswa yang 
memiliki kecerdasan interpersonal tinggi diajarkan dengan model pembelajaran kooperatif NHT $\left(\mathrm{A}_{2} \mathrm{~B}_{1}\right)$ dibandingkan kelompok siswa yang memiliki kecerdasan interpersonal rendah diajarkan dengan model pembelajaran kooperatif $\mathrm{NHT} \quad\left(\mathrm{A}_{2} \mathrm{~B}_{2}\right)$ dengan $F_{\text {hitung }}>F_{\text {tabel }}$ yaitu 535,06>4,16. Berdasarkan skor rata-rata tampak bahwa kelompok siswa yang memiliki kecerdasan interpersonal tinggi diajarkan dengan model pembelajaran kooperatif NHT $(19,29)$ memperoleh hasil belajar matematika yang lebih tinggi dan lebih baik dibandingkan kelompok siswa yang memiliki kecerdasan interpersonal rendah diajarkan dengan model pembelajaran kooperatif TS-TS $(15,81)$.

\section{PEMBAHASAN}

Menggunakan model pembelajaran kooperatif Two Stay Two Stray dalam proses pembelajaran Matematika, siswa dibagi atas beberapa kelompok, di mana setiap kelompok berjumlah 4 orang yang masing-masing memiliki tingkat kemampuan dan latar belakang berbeda. Dari segala perbedaan yang dimiliki siswa, diharapkan akan terjadi pelatihan silang (cross training), sehingga tugas-tugas pembelajaran dapat diselesaikan dengan baik. Hal ini mendukung hasil penelitian Slater (dalam Rahmat (2005), makin besar ukuran kelompok makin berkurang kepuasan anggota-anggotanya. Batas optimal adalah 4 orang perkelompok. Anggota lebih dari 4 orang cenderung dianggap kacau dan menghamburkan waktu oleh anggota kelompok. Berdasarkan hasil penelitian yang dilakukan, bahwa kelompok siswa yang diajar menggunakan strategi pembelajaran kooperatif Two Stay Two Stray memperoleh skor rata-rata hasil belajar 19,77 , sedangkan yang diajar menggunakan model pembelajaran kooperatif Number Head Together memperoleh skor rata-rata hasil belajar 17,47.Dari perbedaan skor rata-rata hasil belajar tersebut setelah dilakukan pengujian terhadap hipotesis ternyata hasil belajar Matematika yang diajar menggunakan model pembelajaran kooperatif Two Stay Two Stray lebih tinggi dari pada yang diajar menggunakan model pembelajaran kooperatif Number Head Together. Hal ini dapat disebabkan, bahwa dengan menggunakan model pembelajaran Two Stay Two Stray siswa akan merasa lebih segar dan berupaya bagaimana menghadapi suasana baru, pasangan anggota baru dalam kelompok belajarnya. Dengan suasana baru ini, siswa akan mendapatkan penampilan baru, perpektif sosial yang baru untuk berinteraksi dengan temantemannya. Hal ini juga sesuai dengan pendapat Lie (2003) yang menyatakan, pengelompokan dapat sering diubah untuk setiap kegiatan. Jika kelompok sering diubah, siswa akan mempunyai kesempatan untuk berinteraksi dengan siswa lainnya. Jadi dengan bertukar pasangan siswa juga lebih banyak menjalin persahabatan, tukar informasi, kerja sama, sehingga dapat melatih mengembangkan keterampilan sosial.

Apabila siswa telah memiliki keterampilan sosial yang baik, maka akan membantu dalam mengatasi masalah-masalah dalam belajar. Dalam belajar, siswa selalu merasa senang, bergairah tidak ada rasa beban. Hal ini sesuai penelitian Simanjuntak (2001) yang mengemukakan bahwa semakin baik intensitas rasa saling memiliki (cohesivenes) dalam kelompok maka semakin tinggi pula kadar partisipasi anggota sehingga tujuan kelompok dapat tercapai secara optimal. Berbeda dengan model pembelajaran kooperatif Number Head Together, di mana setiap kegiatan pembelajaran, siswa menyelesaikan tugas hanya sendiri. Tugas tugas belajar dikerjakan oleh masing-masing siswa, sehingga terasa beban dalam pembelajaran lebih berat. Siswa terbatas dalam tukar informasi, kurang terlatih untuk mengembangkan keterampilan sosial. Hal ini dapat saja menimbulkan kejenuhan. Dengan demikian apabila siswa telah mengalami kejenuhan ataupun kebosanan dalam belajar, ini dapat mengganggu proses pembelajarannya. Apabila siswa merasa ada beban, ini semua akan dapat menghambat

dalam mencapai hasil belajar. Dalam proses pembelajaran Sosiologi yang dilakukan secara berkelompok, diharapkan semua siswa aktif bekerja sama, mampu menanggapi pembicaraan sesama siswa, saling memberi masukan, sehingga dapat membentuk dan menghasilkan kesepakatan bersama yang tepat/benar. Hal ini akan dapat terwujud apabila siswa memiliki tingkat kecerdasan interpersonal yang baik. Menurut Gardner (1999) yang dikutip Campbell, dkk (2006), bahwa kecerdasan interpersonal merupakan kemampuan seseorang untuk memahami dan berinteraksi dengan orang lain secara efektif.

Berdasarkan hasil penelitian yang dilakukan, bahwa kelompok siswa yang memiliki tingkat kecerdasan interpersonal tinggi memperoleh skor rata-rata hasil belajar 36,75 sedangkan yang memiliki tingkat kecerdasan 
interpersonal rendah memperoleh skor rata-rata 31,35. Hal ini cukup beralasan, karena siswa yang memiliki tingkat kecerdasan interpersonal tinggi lebih mampu berbicara dengan efektif, cepat memahami, cepat tanggap terhadap tempramen, sifat, kepribadian temannya. Sudah tentu siswa dengan kemapuan berkomunikasi yang baik akan lebih memiliki kecakapan sosial, sehingga mampu melihat kemungkinankemungkinan perilaku yang diterima ataupun tidak diterima. Selanjutnya ditinjau dari kecakapan behavioral juga siswa tersebut cepat membaca situasi tentang apa, kapan dan bagaimana yang harus dilakukan terhadap teman. Dengan demikian lebih mudah untuk mengatasi segala hambatan ataupun permasalahan belajarnya. Sementara siswa yang memiliki tingkat kecerdasan interpersonal rendah, sulit untuk mengadakan komunikasi yang baik. Kadang kala siswa tersebut mangalami salah pengertian/ salah tafsir terhadap apa yang disampaikan teman belajarnya. Selain itu bahwa siswa yang memiliki kecerdasan interpersonal rendah ini, kurang dapat menciptakan percakapan yang efektif, kurang terlibat dalam menyampaikan argumentasi, bahkan lambat menyerap informasi. Para siswa ini lebih banyak diam, dan malu. Siswa-siswa yang memiliki tingkat kecerdasan interpersonal rendah banyak mengalami hambatan-hambatan dalam proses belajar yang akhirnya mempengaruhi hasil belajar yakni kurang dapat mencapai hasil belajar seperti siswa yang memiliki kecerdasan interpersonal tinggi.

Berdasarkan pengujian hipotesis penelitian, diperoleh bahwa terdapat interaksi antara model pembelajaran kooperatif dan kecerdasan interpersonal siswa terhadap hasil belajar Matematika. Berarti variabel model pembelajaran kooperatif dan kecerdasan interpersonal secara bersama-sama mempengaruhi hasil belajar siswa. Dari hasil pengujian lanjutan diperoleh bahwa skor ratarata hasil belajar untuk kelompok siswa yang memiliki tingkat kecerdasan interpersonal tinggi pada kelas yang menggunakan model pembelajaran kooperatif Two Stay Two Stray memiliki skor rata-rata hasil belajar 22,13 lebih tinggi dari pada kelas yang menggunakan model pembelajaran kooperatif Number Head Together yang hanya 19,28. Hal ini disebabkan bagi siswa yang memiliki kecerdasan interpersonal tinggi pada kelas yang menggunakan model pembelajaran kooperatif Two Stay Two Stray lebih banyak menjalin komunikasi dengan teman belajar. Dengan empat kali pertemuan terdapat empat kali pula ganti pasangan anggota. Empat kali bertamu pada kelompok lain dan juga teman kelompoknya akan empat kali pula menerima tamu dari kelompok lain. Siswa lebih banyak terlatih dalam mengembangkan kecakapan berkomunikasi, sehingga tidak tertutup kemungkinan lebih berani bertanya tentang permasalahan belajarnya kepada siapa saja, karena siswa tidak canggung tidak malu untuk bertanya dan berdiskusi Untuk siswa pada kelas model pembelajaran kooperatif Number Head Together, kurang dalam tukar informasi.

Temuan lain dari hasil penelitian ini adalah skor rata-rata hasil belajar siswa yang memiliki tingkat kecerdasan interpersonal tinggi pada kelas model pembelajaran kooperatif Number Head Together adalah 19,28 tidak berbeda secara signifikan dari pada siswa yang memiliki tingkat kecerdasan interpersonal rendah pada kelas kooperatif Two Stay Two Stray yakni 17,4. Hal inidikarenakan siswa yang memiliki tingkat kecerdasan interpersonal rendah kurang mampu dalam menghadapi situasi baru dengan pergantian pasangan anggota kelompok. Setiap pertemuan siswa kembali pidah untuk bertamu pada kelompok lain, kekurangan dalam kemampuan berkomunikasi mengakibatkan siswa kurang percaya diri, rasa malu. Sesuai yang dikatakan Safaria (2005) yaitu bisa dibayangkan ketika harus bekerja dan belajar secara berkelompok kemudian rasa malu menyebabkannya menyingkir dari kegiatan bersama tersebut.

Siswa yang tidak mampu bekerjasama dengan teman belajar akan cenderung tersisih. Saat memasuki kelompok baru, ada rasa cemas bagimana berbicara yang baik, bagaimana seharusnya untuk menyesuaikan diri. Semua dapat mempengaruhi hasil belajar siswa. Selanjutnya skor rata-rata hasil belajar siswa yang memiliki tingkat kecerdasan interpersonal tinggi pada kelas kooperatif Two Stay Two Stray $=42,80$ lebih tinggi dari pada skor rata-rata hasil belajar siswa yang memiliki tingkat kecerdasan interpersonal rendah pada kelas kooperatif Two Stay Two Stray 17,4. Di sini juga jelas bahwa siswa yang memiliki kecerdasan interpersonal tinggi pada kelas kooperatif Two Stay Two Stray telah terlatih betul dalam bekerja sama dengan pasangan anggota kelompok manapun. Sesuai dengan pernyataan Gunawan (2003), siswa dengan kecerdasan interpersonal yang 
berkembang dengan baik akan menikmati kegiatan kelompok.

Siswa juga sangat suka dengan kegiatan yang mengharuskan melakukan pengamatan, interaksi manusia, wawancara, menetapkan aturan kelas, menentukan atau membagi tugas dan tanggung jawab serta mengikuti permainan yang melibatkan upaya menyelesaikan konflik. Untuk siswa yang memiliki tingkat kecerdasan interpersonal tinggi pada kelas kooperatif Number Head Together memperoleh skor ratarata hasil belajar 19,28 , tidak berbeda secara signifikan dengan siswa yang memiliki tingkat kecerdasan interpersonal rendah pada kelas Number Head Together. Ini juga sudah barang tentu disebabkan kemampuan/ kecakapan berbicara siswa yang berbeda.

Siswa dengan kecakapan komunikasi yang lebih tinggi tidak dapat menyalurkan aspirasi atau berdiskusi dengan teman, karena dalam model pembelajaran kooperatif Number Head Together. Kemudian dalam penelitian ini ditemukan juga siswa yang memiliki tingkat kecerdasan interpersonal rendah pada kelas model pembelajaran kooperatif Number Head Together skor rata-rata hasil belajar 15,81 tidak berbeda secara signifikan dari pada siswa yang memiliki tingkat kecerdasan interpersonal rendah pada kelas kooperatif Two stay Two Stray dengan skor rata-rata hasil belajar 17,4. Ini menunjukan bahwa siswa lambat menyesuaikan diri terhadap situasi, teman baru dalam kelompoknya karena kemampuan berkomunikasi yang kurang. Selain itu bahwa siswa dengan tingkat kecerdasan interpersonal rendah lebih dapat belajar dengan baik apabila teman belajar tanpa berkelompok. Temuan terakhir dalam penelitian ini, siswa yang memiliki tingkat kecerdasan interpersonal tinggi pada kelas kooperatif Two stay Two Stray memiliki rata-rata skor hasil belajar adalah 22,13 berbeda secara signifikan dengan rata-rata skor hasil belajar siswa yang memiliki kecerdasan interpersonal rendah pada model pembelajaran kooperatif Number Head Together yakni 15,81. Hal ini juga telah jelas bahwa siswa yang memiliki tingkat kecerdasan interpersonal tinggi akan lebih senang dalam belajar secara kelompok, dan siswa yang memiliki kecerdasan interpersonal rendah labih senang belajar secara individual.

Dari hasil temuan-temuan hasil penelitian ini maka model pembelajaran kooperatif Two stay Two Stray, lebih sesuai digunakan pada siswa yang memiliki tingkat kecerdasan interpersonal tinggi, sedangkan model pembelajaran kooperatif Number Head Together, lebih sesuai digunakan pada siswa yang memiliki tingkat kecerdasan interpersonal rendah.

\section{PENUTUP}

Berdasarkan hasil dan pembahasan penelitian, maka dapatlah ditarik beberapa simpulan seperti di bawah ini :

1. Terdapat perbedaan hasil belajar Matematika pada siswa yang diajar menggunakan model pembelajaran kooperatif Two Stay Two Stray dengan siswa yang diajar menggunakan model pembelajaran kooperatif Number Head Together. Dengan kata lain, skor ratarata hasil belajar Matematika pada kelas yang menggunakan model pembelajaran kooperatif Two Stay Two Stray lebih tinggi dari pada yang menggunakan model pembelajaran kooperatif Number Head Together.

2. Terdapat perbedaan hasil belajar Matematika pada siswa yang memiliki tingkat kecerdasan interpersonal tinggi dengan siswa yang memiliki tingkat kecerdasan interpersonal rendah. Dengan kata lain siswa yang memiliki tingkat kecerdasan interpersonal tinggi memperoleh skor rata-rata hasil belajar lebih tinggi dari pada siswa yang memiliki tingkat kecerdasan interpersonal rendah.

3. Terdapat interaksi antara model pembelajaran kooperatif dan kecerdasan interpersonal terhadap hasil belajar Matematika. Dari hasil pengujian lanjutan diperoleh bahwa siswa yang memiliki tingkat kecerdasan interpersonal tinggi memperoleh hasil belajar lebih tinggi jika diajar menggunakan model pembelajaran kooperatif Two Stay Two Stray dibandingkan apabiladiajar menggunakan model pembelajaran kooperatif Number Head Together dan siswa yang memiliki kecerdasan interpersonal rendah lebih tinggi hasil belajarnya jika diajar menggunakan model pembelajaran kooperatif Number Head Together dibandingkan apabila diajar menggunakan model pembelajaran kooperatif Two Stay Two Stray.

\section{DAFTAR PUSTAKA}

Asmani, Jamal Ma'mur. 2009. Jurus - Jurus Belajar Efektif untuk SD dan SMP. Yogyakarta : DIVA Press. 
Bungin, Burhan. 2007. Sosiologi Komunikasi. Jakarta: Kencana Prenada Media Dahar, Ratna Wilis. 2006. Teori-teori Belajar\&Pembelajaran. Jakarta: Erlangga.

Gunawan, Adi W. 2007. Genius Learning Strategy. Jakarta: PT.Gramedia Pustaka

Hamid K, Abdul. 2007. Teori Belajar dan Pembelajaran. Medan: Pascasarjana UNIMED.

Hamalik, Oemar. 2001. Proses Belajar Mengajar. Jakarta: PT.Bumi Aksara

Huda, Miftahul. 2011. Cooperative Learning. Yogyakarta: Pustaka Pelajar

Indrawati, Surya. 2012. Pengaruh Pembelajaran Kooperatif Terhadap Hasil Belajar Peserta Didik di SD Negeri 064978 Medan. http://digilib.unimed.ac.id. diakses 24 Januari 2014.

Johnson, David W., dkk. 2010. Colaborative Learning. Bandung: Nusa Media

Lie, Anita. 2010. Cooperative Learning. Jakarta: Grasindo

Nazar, Muhammad. 2009. Matematika untuk SD/MIN kelas IV. Surakarta : Inti Prima Aksara.

Panjaitan, Keisar. 2009. Pendidikan Masa Depan. Gorontalo: BMT Nurul Jannah

Panjaitan, Keisar. 2010. Merancang Butir Soal dan Instrumen Untuk Penelitian. Gorontalo: BMT Nurul Jannah.

Rahmayanti, Yuna. 2012. Pengaruh Pembelajaran Kooperatif dan Media terhadap Hasil Belajar Kimia Siswa Pada Pokok Bahasan Struktur Atom Kelas XI SMA. http://digilib.unimed.ac.id. diakses 24 Januari 2014.

Reid, Gavin. 2009. Memotivasi Siswa di Kelas. Jakarta: PT. Indeks.
Rusman, 2010. Model - Model Pembelajaran Mengembangkan Profesionalisme Guru. Jakarta : PT. RajaGrafindo.

Sari, Rita. 2012. Pengaruh Pembelajaran Kooperatif dan Kecerdasan Interpersonal Terhadap Peningkatan Hasil Belajar Biologi Kelas XI IPA 3 MAN 2 Tanjung Pura. http://digilib.unimed.ac.id. diakses 24 Januari 2014.

Siska, Firayanti. 2012. Pengaruh Model Pembelajaran Kooperatif Terhadap Hasil Belajar Akuntansi Siswa Kelas XI IPS SMA Negeri 1 Kuala. http://digilib.unimed.ac.id. diakses 24 Januari 2014.

Slavin, Robert E. 2005. Cooperative Learning. Bandung: Nusa Media.

Sudjana, Nana \& Wari Suwariyah. 1991. Model - Model Mengajar CBSA.

Bandung : Sinar Baru Bandung.

Sudjana. 2002. Metode Statistika. Tarsito : Bandung.

Sugiyono. 2009. Metode Penelitian Pendidikan. Bandung: CV. Alfabeta.

Suherman, Erman. 2001. Evaluasi Proses dan Hasil Belajar Matematika.Jakata : Pusat Penerbitan Universitas Terbuka.

Sumaini, Sri \&Warsono.2013. LKS Matematika Medali Kelas IV SD Semester Genap. Jakarta:Indonesia Jaya.

Suparman, Atwi. 2012. Desain Instruksional Modern. Jakarta: Erlangga.

Supatmono, Catur. 2009. Matematika Asyik. Jakarta : PT. Gramedia Widiasarana Indonesia

Uno, Hamzah B. 2007. Model Pembelajaran Menciptakan Proses Belajar Mengajaryang Kreatif dan Efektif. Jakarta : Bumi Aksara. 